HUMANIORA ISLAMICA II 



\section{HUMANIORA ISLAMICA}

An Annual Publication of

Islamic Studies and the Humanities

Volume II/1974

Edited by HERBERT W. MASON

University Professor of Islamic Studies

Boston University

Boston, Mass., U.S.A.

RONALD L. NETTLER

Associate Professor of Religion

Carleton University

Ottawa, Canada

\section{MERLIN L. SWARTZ}

Associate Proffessor of Islamic Studies

Boston University

Boston, Mass., U.S.A.

JACQUES WAARDENBURG

Department of Religious Studies

University of Utrecht

The Netherlands 
Manuscripts for the next volumes may be submitted, in English, to the Editors of Humaniora Islamica at the following addresses:

Within the U.S.A. and Canada:

Suite 500, Boston University, 270 Bay State Road, Boston, Mass. 02215.

Outside North America:

c/o J. D. J. Waardenburg, University of Utrecht, Heidelberglaan 2, Utrecht, The Netherlands.

No specific length is prescribed for contributions, but authors must confine themselves to the minimum required by the subject matter, and the same applies to tables and footnotes. All tables, illustrations, and footnotes should be together at the end, with indications in the text as to where they are to be located. Three copies of the typescript, in double spacing, should be sent to the Editors.

Subscriptions, single or back issues may be ordered through any bookseller or subscription agent, or direct from the publishers:

MOUTON, P.O. Box 482, The Hague, Netherlands

7 rue Dupuytren, 75006 Paris, France

Distribution in the U.S.A. and Canada:

The Macfarland Company

1716 East Second Street, Scotch Plains, N.J. 07076.

Cheques, bank drafts, money orders and Unesco coupons will be accepted in payment and should accompany orders.

ISBN 2-7193-0608-8

Library of Congress Catalog Card Number: 73-81811

Cover design by Helmut Salden

(C) 1974 The Editors

Printed in Hungary 